\title{
Tell and Let Know: A Corpus-Based Study
}

\section{Christian Misuro \\ English Instructor}

\section{Reference Data:}

Misuro, C. (2020). Tell and let know: A corpus-based study. In P. Clements, A. Krause, \& R. Gentry (Eds.), Teacher efficacy, learner agency. Tokyo: JALT. https://doi.org/10.37546/JALTPCP2019-31

This paper is based on research into the usage of the terms tell and let know, using data from the British National Corpus of English and the Corpus of Contemporary American English. The differences between them, as well as the extent and character of their synonymy, are analyzed through corpus distribution and semantic preferences. The results indicate subtle differences between the terms. Though they are partially synonymous, tell is more often selected in reference to anecdotal and incidental transmission of information, such as when discussing past events, and thus has a wider idiomatic usage. Let know replaces tell in cases of direct requests, offers or demands. It is hypothesized that this may result from the inherent indirectness of the term when compared to tell, and thus its perceived politeness. The study also demonstrates the use of corpora to increase effectiveness of instructional explanations of differences in usage between similar terms.

本論文は、British National Corpus of English及びCorpus of Contemporary American Englishのデータから、現代英語に て「tell」及び「let know」の用語使用を調べた研究に基づいたものである。それぞれのコーパス内の分布や意味表現の考察 を通し、相互の違いや類似の範囲や特性を分析する。研究の結果から用語の微妙な違いが示される。用語は部分的には同義 であるが、「tell」は、比較的に、過去または偶発的事柄の伝達に使われることが多く、幅広く慣用句として使用されている。 「let know」は、直接的依頼や、提案、要求の場合「tell」の代わ㤱使用される「tell」と比較してこの用語が元々持つ間接的もし くは受動性が礼儀正しいものと認識されていることに起因するものと仮定される。また、本研究では、類似する言い回しの違 いの説明を授業で効果的にするコーパスの使用例を示す。

' his is a corpus-based comparison of the verb tell and the phrase let know. It

demonstrates, through concordance analysis of the lexical environment of these near-synonyms, how they differ in aspects of use despite outward semantic similarities.
Both the advantages and limitations of using corpora in a study like this are also discussed.

In the first section background literature concerning the concepts related to this study is reviewed, including synonymy and the relationship between semantics and lexical environment. The second section begins with a closer look at the terms to be analyzed, followed by a description of the methodology of the study. The results of the study and my conclusions about the actual usage of the terms then follow, as well as a discussion of its implications for the use of corpora in language instruction and the limitations imposed by the corpora on comprehensiveness.

\section{Literature Review \\ Synonymy}

As background to his corpus-based study of the word sheer and semantically similar items, Partington (1998, following Lyons, 1977, 1981) outlines a definition of synonymy in which he mentions three types: complete, absolute and descriptive. Terms are completely synonymous if they have the same meaning in a certain range of contexts and absolutely synonymous if they have the same meaning in absolutely all contexts, which is thought to be very rare. According to Lyons (1977), items are descriptively synonymous if exchanging one term for another changes the social or expressive meaning of the utterance but retains its descriptive meaning: In other words, as one might call this saying the same thing in a different way in response to situational context.

Partington (1998) also follows Kempson (1977) in linking synonymy to mutual entailment. The phrases I am thirsty and I would like something to drink might be seen as examples of mutual entailment. More pertinent to this study, however, is the relationship between non-mutually-entailing terms, which is that of hyponym to superordinate. Partington gives the example of the hyponym cat to the superordinate animal. A cat is always an animal but an animal is not always a cat; the term animal encompasses a whole 
family of other terms. Partington's study of the differences between near-synonyms is an example of the advantage of using corpora for this purpose: It allows a broader range of data about language in use to be analyzed than what intuition alone allows.

\section{Corpora, Meaning and Lexical Environment}

When J. R. Firth said, "You shall judge a word by the company it keeps" he was referring to the close relationship between word meaning and lexical environment. Firth first used the phrase "meaning by collocation" to express the effect that surrounding words have of delineating meaning (Firth, 1957, cited in Partington, 1998, p. 15). In Corpus, Concordance and Collocation, Firth's student John Sinclair also examines the relationship between what he refers to as "sense and syntax" (1991, p. 65), as well as the value of corpora in its study. He defines a collocate as "any word that occurs in the specified environment of a node" (1991, p. 115), or the word at the center of a corpus concordance line. His corpus-based study of the phrasal verb set in shows how the linguistic environment of the phrase elucidates meaning, distinguishing it from other phrasal verbs based on the verb-element set, and that even larger multiple-word constructions can also constitute a single linguistic choice (1991).

This is Sinclair's idiom principle: that language is largely composed of "semipreconstructed phrases that constitute single choices, even though they might appear to be analyzable into segments" (1991, p. 110). Two-word separable verbs like let know then, are amongst the more flexible members of the smallest units of language that provide evidence for the idiom principle. Sinclair (1991) also links the phenomenon of collocation to register. Hunston defines register as "discourse occurring in a particular context" and notes that word meaning and use sometimes vary with register (2002, p. 160-161). Partington agrees with Sinclair that "collocational normality" depends on "genre, register and style, i.e. what is normal in one kind of text might be quite unusual in another" (1998. p. 17)

\section{Lexical Priming}

Hoey (2004) argues that lexical items are primed for collocational use. Priming refers to word meaning accumulated through encounters with it in use, in such a way that frequent collocates come to constitute part of one's knowledge of the word itself. Word acquisition, according to Hoey, involves knowing all aspects of priming, including collocation and semantic associations. He notes, with a nod toward register, the sensitivity of collocational priming to the domain in which it is encountered. He notes also that priming is not permanent; meanings can shift as each encounter with a word strengthens or weakens its priming (Hoey, 2004).

\section{Tell and Let Know: Meanings and Definitions}

The terms tell and let know were chosen based on my initial intuitive perception of them as both complete and descriptive synonyms. Tell seems to have a wider use; there are many ways to tell someone something, some of which were mentioned above. Let know, then, seems at first glance to be a hyponym within the superordinate tell family.

\section{Dictionary Definitions}

The online version of the COBUILD Advanced British English Learner's Dictionary (Collins, 2020) gives several pertinent definitions for tell (Table 1). Because it is a phrase, there is no independent entry for let know in the dictionary. A sub-entry to the definition of let is included in the Table 2, as well as a simple definition from the Cambridge Advanced Learner's Dictionary (Cambridge University Press, 2020).

\section{Table 1. Dictionary Definitions for Tell}

\begin{tabular}{|c|c|c|}
\hline Part of speech & Definition & Example \\
\hline Verb & $\begin{array}{l}\text { If you tell someone something, you give } \\
\text { them information. }\end{array}$ & $\begin{array}{l}\text { In the evening I returne } \\
\text { to tell Phyllis our } \\
\text { relationship was over. }\end{array}$ \\
\hline Verb & $\begin{array}{l}\text { If you tell something such as a joke, a } \\
\text { story, or your personal experiences, you } \\
\text { communicate it to other people using } \\
\text { speech. }\end{array}$ & $\begin{array}{l}\text { His friends say he was } \\
\text { always quick to tell a } \\
\text { joke. }\end{array}$ \\
\hline Verb & $\begin{array}{l}\text { If you tell someone to do something, you } \\
\text { order or advise them to do it. }\end{array}$ & $\begin{array}{l}\text { A passer-by told the } \\
\text { driver to move his car sc } \\
\text { that it was not causing } \\
\text { an obstruction }\end{array}$ \\
\hline Verb & $\begin{array}{l}\text { If you tell yourself something, you put it into } \\
\text { words in your own mind because you need } \\
\text { to encourage or persuade yourself about } \\
\text { something. }\end{array}$ & $\begin{array}{l}\text { "Come on," she told } \\
\text { herself. }\end{array}$ \\
\hline
\end{tabular}


Misuro: Tell and Let Know: A Corpus-Based Study

\begin{tabular}{lll}
\hline Part of speech & \multicolumn{1}{c}{ Definition } & \multicolumn{1}{c}{ Example } \\
\hline Verb & $\begin{array}{l}\text { If you can tell what is happening or what is } \\
\text { true, you are able to judge correctly what is } \\
\text { happening or what is true. }\end{array}$ & $\begin{array}{l}\text { It was already impossible } \\
\text { to tell where the bullet } \\
\text { had entered }\end{array}$ \\
Verb & $\begin{array}{l}\text { If facts or events tell you something, they } \\
\text { reveal certain information to you through } \\
\text { ways other than speech. }\end{array}$ & $\begin{array}{l}\text { The facts tell us that this } \\
\text { is not true. }\end{array}$ \\
Convention \\
(informal) & $\begin{array}{l}\text { You can say I tell you, I can tell you, or I can't } \\
\text { tell you to add emphasis to what you are } \\
\text { saying. }\end{array}$ & $\begin{array}{l}\text { I tell you this, I will not } \\
\text { rest until that day has } \\
\text { come. }\end{array}$ \\
\hline
\end{tabular}

Table 2. Dictionary Definitions for Let Know

\begin{tabular}{llll}
\hline \multicolumn{1}{c}{ Source } & Part of speech & \multicolumn{1}{c}{ Definition } & \multicolumn{1}{c}{ Example } \\
\hline $\begin{array}{l}\text { COBUILD Advanced } \\
\text { British English } \\
\text { Learner's Dictionary }\end{array}$ & Phrase & $\begin{array}{l}\text { If you let someone know } \\
\text { something, you tell them } \\
\text { about it or make sure that } \\
\text { they know about it. }\end{array}$ & $\begin{array}{l}\text { They want to let } \\
\text { them know that } \\
\text { they are safe. }\end{array}$ \\
$\begin{array}{l}\text { Cambridge British } \\
\text { English Dictionary }\end{array}$ & Phrase & To tell someone something. & $\begin{array}{l}\text { Let us know when } \\
\text { you get there. }\end{array}$ \\
\hline
\end{tabular}

\section{Commentary}

Intuitive conclusions about the wider usage of tell, then, are supported by the dictionary definition. Let know seems so far also to conform to intuition, being a synonym in both dictionary entries. A possible divergence in meaning is evident only in the second part of the COBUILD entry, “... or make sure that they know about it” (Collins, 2020).

\section{Methodology}

Usage of tell and let know was investigated in two corpora, and the results compared. In each case, the distribution of the the term within the corpus was first noted. Distribution of let know was analyzed using searches for the verb lemma let followed within six spaces by know, to allow for the flexible size of the sentence object. This was followed by an examination of usage in sample concordance lines and an analysis of collocations to the left and right of both terms.

\section{Corpora Used}

To account for variations between different varieties of English, two corpora were used in the study: The British National Corpus (BNC; 2001) and the Corpus of Contemporary American English (COCA; Davies, 2008). The BNC is a 100 million-word database of British English. The first additions date from the late 1980s and the last were made in 1993 . Its content is $90 \%$ written, coming from sources such as newspapers, fiction, academic journals, magazines and many others. The spoken content is composed of recordings of informal conversations, as well as trancripts of radio shows, meetings and other sources.

The much larger COCA contains more than 560 million words of American English 20 million words were added to the corpus per year between 1990 and 2019. It is $85 \%$ written, from sources such as magazines, newspapers, academic journals and fiction. The spoken content is composed of transcripts of television and radio programs among other sources.

\section{Results}

\section{Distribution}

General similarities in distribution across corpora were evident. The verb lemma tell appeared over 50 times more often than let know in each, and was much more common in spoken English than written. In the BNC the term was most common in the subcategory of spontaneous conversation, which does not appear in the COCA database. There tell appeared most often in broadcast media texts and interviews, where it was also common in the BNC. Regarding written texts, both tell and let know were most common in both corpora in fiction. In both corpora, however, tell was common in newspapers, where let know appeared less. A breakdown of the distribution of the terms in both corpora is shown in the following tables: 
Misuro: Tell and Let Know: A Corpus-Based Study

Table 3. Term Distribution in the BNC (Frequency per Million Words)

\begin{tabular}{lrc}
\hline \multicolumn{1}{c}{ Corpus section } & Tell & Let know \\
\hline Overall & 724.97 & 14.01 \\
Spoken & 1223.85 & 30.41 \\
Fiction & 1830.56 & 28.10 \\
Magazine & 458.97 & 12.12 \\
Newspaper & 876.52 & 5.45 \\
Non-academic & 351.86 & 3.88 \\
Academic & 198.22 & 2.15 \\
Miscellaneous & 471.80 & 19.63 \\
\hline
\end{tabular}

Table 4. Term Distribution in the COCA (Frequency per Million Words)

\begin{tabular}{lcc}
\hline \multicolumn{1}{c}{ Corpus section } & Tell & Let know \\
\hline Overall & 1029.82 & 18.75 \\
Spoken & 1374.42 & 27.22 \\
Fiction & 1647.81 & 29.03 \\
Magazine & 964.67 & 19.92 \\
Newspaper & 719.56 & 10.84 \\
Academic & 246.20 & 3.43 \\
\hline
\end{tabular}

A difference between the corpora was the higher overall frequency of let know in the COCA corpus (18.75 tokens per million words [fpm]) compared to the BNC (14.01 $\mathrm{fpm})$. This reflects a trend of increasing usage over time in the COCA, from $13.48 \mathrm{fpm}$ in 1990 to $21.70 \mathrm{fpm}$ in 2019. This may be due to a shift to digital media; amongst the concordance lines from 2017, for example, are many calls from websites or magazines for feedback from the reader via email or comments, as in the following concordance line: "Will you add or start your Mark Hamill shrine with the Joker? Let me know on Twitter or sound off in the comments below" (Davies, 2008).

\section{Concordance Samples}

Concordance Samples for Tell

Usage of tell corresponded well to the Collins dictionary definitions given above. The majority of concordance lines referred to direct transmission of information, or communication using speech. In this context, many concordance lines featuring the verb were in past tense. Also represented in the samples in both corpora were lines corresponding to the other dictionary definitions above, as shown in Table 5.

\section{Table 5. Concordance Line Examples for Tell}

Concordance lines (COCA, 2020 and Dictionary definitions

$$
\mathrm{BNC}, 2001)
$$

He came to the Matrix and saw us and told some people that he dug us.

If you tell someone something, you give them And there's a story you tell in your essay about learning...

I was screaming, telling my neighbors to stop him.

It's not cooked yet, she told herself.

He said, 'I can tell a smoker's hair since it's more dull... information.

If you tell something such as a joke, a story, or your personal experiences, you communicate it to other people using speech.

If you tell someone to do something, you order or advise them to do it.

If you tell yourself something, you put it into words in your own mind because you need to encourage or persuade yourself about something.

If you can tell what is happening or what is true, you are able to judge correctly what is happening or what is true.

Yet some instinct told me that I must be careful to give her no cause...

If facts or events tell you something, they revea certain information to you through ways other than speech.

But tell me, how many secretaries you know make $\$ 100,000$ a year? You can say I tell you, I can tell you, or I can't tell you to add emphasis to what you are saying.

Note. Tell as it appeared in the concordance lines corresponded to the dictionary definitions provided. 


\section{Concordance Samples for Let Know}

Concordance lines in both corpora for let know showed the frequent use of the phrase to offer, request or demand information. Most of the sentences for both corpus samples used first or second-person pronouns, and imperatives were common. The concordance lines also demonstrated the use of let know, perhaps referred to in the second half of the Collins dictionary definition (“...or make sure that they know about it.") to mean transmission of information by non-verbal or non-explicit verbal means, as in the Table 6 .

\section{Table 6. Concordance Line Examples for Let Know}

\begin{tabular}{ll}
\hline Concordance lines (COCA, 2020 and BNC, 2001) & \multicolumn{1}{c}{ Usage } \\
\hline $\begin{array}{l}\text { 'Let me know when it's ready for another pair of } \\
\text { eyes,' I said. }\end{array}$ & $\begin{array}{l}\text { Offers of, requests/demands for } \\
\text { information (1st or 2nd-person) }\end{array}$ \\
$\begin{array}{ll}\text { Now she had to let her husband know, oh-so- } \\
\text { artlessly, that she had set a guard on Marion that }\end{array}$ & $\begin{array}{l}\text { Giving information by nonverbal } \\
\text { cues }\end{array}$ \\
$\begin{array}{ll}\text { he couldn't break without scandal. } & \end{array}$ \\
$\begin{array}{ll}\text { Let the customer know that you understand her } \\
\text { requirements, e.g., 'I see, you want a set of four }\end{array}$ & $\begin{array}{l}\text { Giving information by nonexplicit } \\
\text { verbal cues }\end{array}$
\end{tabular}
saucepans.'

This usage is unique to let know; tell would change the meaning here. In contrast then to assumptions made before the research, tell appears to be a hyponym of the superordinate term let know, as it implies a verbal transmission of information that is not the only way to let someone know something (the term show, for example, might also be included here).

\section{Collocational Analysis}

Top collocations in the BNC were measured by log likelihood (LL) value and mutual information (MI) score, two common ways of measuring statistical significance of collocational frequency in corpora. These values were chosen as LL value focuses more on higher-frequency collocations, while MI is seen more as a diagnostic of "lexical behavior" and brings in less frequent word collocates (Hunston, 2002, p. 74). Collocations in the COCA were measured by raw frequency of the term in the corpus and by MI score, as the corpus tools there do not sort data by log likelihood. To isolate differences in usage between the terms, only collocates that were among the top 50 for one term and not the other were included in the analysis; all collocates that appeared strongly with both tell and let know were eliminated from consideration (See Appendix A through D). All collocates analyzed appeared in at least four texts. As with distribution results, overall similarities were noted between the British and American English databases.

\section{Significant Patterns Within Top 50 Collocates of Tell}

The preference for the verb tell in reported speech was apparent in the concordance lines for both corpora (See Appendix A and B), revealed by a semantic preference for mediarelated nouns such as reporters and police, as well as the names of websites and news outlets. Collocations also substantiate some of the other dictionary definitions. The use of tell for relating experiences is demonstrated by semantic preference for a wide range of terms meaning stories, jokes, or lies. Adverbial collocates of modality around tell, such as bluntly or curtly, reflect its use in descriptive relation of experiences or anecdotes. The use of the verb in expressions of emphasis is demonstrated by collocation with a corresponding set of terms, such as let and lemme. Finally the non-verbal use of the term to describe perception is apparent from a set of noun collocates including gut and instincts.

\section{Significant Patterns Within the Top 50 Collocates of Let Know}

Most of the top 50 collocates that were more significant with let know than tell relate to offers of and demands or requests for information, the primary use revealed in the concordance lines above (See also Appendix C and D). In this context, it shows a preference for a range of modifiers, including dominant clause processes such as asked and wanted. Modal terms expressing politeness, such as grateful, were frequent collocates, as were terms of obligation such as important and the imperative modifier please.

Frequent verbiage collocates were also terms appearing in requests, demands or offers. These included circumstances of time, such as in advance, as well as words describing conditions or results, such as safely or happens. Finally the increasing use of the term in American English in requests for feedback, accompanying the shift to digital media, was apparent in the COCA corpus with frequent collocates such as comments and also social networking site names, including both Twitter and Facebook. 


\section{Analysis}

The evidence seems to indicate that tell is comparatively preferred for anecdotal descriptions and in incidental references to transmission of information. That is to say, it is used either to relate past experiences or events, or accompanies[?] other more significant information. Let know replaces it in cases of direct requests, offers and demands, and references to these.

\section{Use of Tell}

The use of tell to describe experiences encompasses its collocations with either sources or receivers of information; thus its frequency in the registers of news, television and radio, where the particular emphasis is usually on the information conveyed or its source, and not the act of communicating itself. Abstractions about content, demonstrated by preference for the story and truth sets of terms mentioned, feature tell used descriptively. Strong collocations referring to manner of communication, such as with adverbs like bluntly or curtly, also indicate an anecdotal use of the term.

The appearance of tell in expressions of emphasis can be described as specifically incidental. The function of these expressions is to highlight what comes after (or before) them, so the focus is once again purely on the content rather than the action of telling itself. This is also true of the frequent collocate trying from the BNC, as follows: "Well I'm telling, that's what l'm trying to tell you" (BNC, 2001).

\section{Use of Let Know}

An important use of let know, as we have seen, is to indicate communication by nonverbal or non-explicit verbal means. The use of let know instead of tell in requests, demands, offers, and references to them explains its preference for first and secondperson pronouns, as well as objects of immediacy such as time restrictions, imperatives, and modality of obligation. This usage may be due to the perceived indirectness or passiveness of the verb element let compared to the "commanding" tone of the verb tell; let seems less intrusive, and thus more polite. In this sense it is a euphemism for tell, and is used for some of the same reasons that imperatives are modalised (Butt et al., 2000). It is in this context that let know has become primed, to use Hoey's term, for use in the register of official correspondence, instructions and commerce-areas where polite requests, offers or demands are common.

\section{Implications for Teaching}

Tell and let know are part of a large body of terms among which native speakers can intuitively percieve differences and (if they are lucky) use correctly in modern Englishspeaking contexts, but often explain only with difficulty. English learners find these differences less naturally apparent, and often make odd-sounding word choices both in class and as they use the language in their lives. Classroom explanations drawn from experiential resources alone in these cases tend to be vague evaluations, such as the dissatisfying, "they mean almost the same thing." This study illustrates the constructive use of corpora to bridge the gap between intuitive and conscious knowledge of lexis. It is intended to show ways in which, with minimal research, corpora can be used to bring intuitive lexical knowledge to a place where it can be explained and demonstrated in the classroom.

\section{Limitations of This Study}

Though the results of this investigation provide a working theory of how these terms are used in British and American English, they cannot be considered comprehensive. Limitations stem from differences in the corpora, available sorting infrastructure, accessibility of corpus data, and corpus composition. Perhaps first and foremost, corpus data for the BNC is from a shorter time periodthat does not include the past 20 years or so, during which the shift to digital media has affected at least the usage of the term let know, as demonstrated. A full study must therefore also include similar data from British English sources. Additionally, the corpora used in the study provide a slightly different range of available online sorting tools. The comparison established here, although presenting a broad and apparently accurate picture of similarities between the two terms, cannot therefore be considered definitive without further research.

Also amongst the problems faced was developing a way to scan the corpora effectively for the phrasal verb let know. Though it is believed that the results obtained provide a good indication of overall use, a more exhaustive study would involve compiling research using a greater range of[?] permutations of search formulae for the phrase.

The balance of source material within the corpora, most significantly the much greater amount of written material than spoken, raises additional questions about the extent to which they can be considered representative of the language as a whole. Furthermore, though usage of the terms appears similar in both, the problem then arises as to how to accurately compare results from corpora composed of slightly different types of material. A comprehensive study would therefore draw upon a sufficiently large, diverse, and 
contemporary range of sources to provide a workable consensus of current usage across the broad spectrum of English varieties.

\section{References}

Butt, D., Fahey, R., Feez, S., Spinks, S., Yallop, C. (2000). Using functional grammar: An explorer's guide (2nd ed.). Sydney: National Center for English Language Teaching and Research, Macquarie University.

Cambridge University Press. (2020). Cambridge advanced learner's dictionary (British English). Retrieved from http://dictionary.cambridge.org/dictionary/british/

Collins. (2020). COBUILD advanced British English learner's dictionary. Retrieved from http://www. collinsdictionary.com/dictionary/english-cobuild-learners/

Davies, M. (2008). The corpus of contemporary American English (COCA): 600 million words, 1990-present. Retrieved October 21, 2019 from https://www.english-corpora.org/coca/

Firth, J. R. (1957). Papers in linguistics. London: Oxford University Press.

Hoey, M. (2004). Lexical priming and the properties of text. In A. Partington, J. Morley and L. Haarman (Eds.), Corpora and discourse (pp 385-412). Bern, Germany: Peter Lang.

Hunston, S. (2002). Corpora in applied linguistics. Cambridge: Cambridge University Press. https:// doi.org/10.1017/СBO9781139524773

Kempson, R. (1977). Semantic theory. Cambridge: Cambridge University Press.

Lyons, J. (1977). Semantics. Cambridge: Cambridge University Press.

Lyons, J. (1981). Language and linguistics. Cambridge: Cambridge University Press. https://doi. org/10.1017/CBO9780511809859

Partington, A. (1998). Patterns and meanings. Amsterdam: John Benjamins. https://doi.org/10.1075/ scl.2

Sinclair, J. (1991). Corpus, concordance, collocation. Oxford: Oxford University Press.

The British National Corpus, version 2 (BNC World). (2001). Distributed by Oxford University Computing Services on behalf of the BNC Consortium. Retrieved from http://www.natcorp. ox.ac.uk/

\section{Appendix A}

Significant Patterns Within Top 50 Collocates of Tell in the BNC

\begin{tabular}{ll}
\hline \multicolumn{1}{c}{ Category } & \multicolumn{1}{c}{ Pattern } \\
\hline Deduction/perception & ca(n't), can, commonsense, could, instinct, \\
& instincts, intuition \\
Dominant clause process & trying
\end{tabular}

Reference to mode of communication phoned

Reported speech

Modality

Media-related sayers/receivers/

clause components

Other sayers/receivers

Subordinate clause process

"Telling oneself" expression

Use for emphasis

Verbiage

Verbiage: stories/jokes

Verbiage: truth/lies am, been, bluntly, curtly did, going, had, have, sternly, truthfully, was, were, 'm, 've,

Accountancy, Aldington, Alitt, conference, Cortauld, court, Gedge, inquest, interviewer, jury, Katharine, Krenz, Mcnealy, Mr, NME,

Orton, Pargeter, pathologist, police, pollsters, Pooh, prosecuting, reporters, Reuter, Reuters, Sadie, spokesperson, Stapleton, Timex,

Unigram, unigram.x, yesterday

mamma, mother, mum, my (friend/relation), someone

happened

herself, himself, myself

let (me tell you), something, 'll

everything, something, news, why

anecdote, gags, gory, hair-raising, jokes,

parable, stories, story, tale, tales

fib, fibs, lies, porkies, truth, untruth, whoppers 


\section{Appendix B}

Significant Patterns Within Top 50 Collocates of Tell in the COCA

Category

\section{Deduction/perception}

Pattern

Dominant clause processes overheard, phoned

Exclamation

Modality of obligation

Reported speech

Modality

Media-related sayers

Media related receivers/clause

components

Other sayers/receivers

\section{gut, instinct, instincts}

shhh

duty-bound

bluntly, do/don't, gruffly, jokingly, laughingly, tearfully, sternly, teasingly

Alberts, Anissa, Axelson, Bakaly, Ben-Menashe, Bowsher, Cataldo, CNNS, Creedon, DeAnn, Deering, defector,

Faruq, Fiers, Gennadi, Glaspie, Gretawire.com, Haidara, Heloise, Hennard, Herridge, informant, Jumblatt,

Katty, Landsbergis, Lavrov, Lewrie, Lyuba, Mcqueary,

Munn, Nuland, O’boyle, Piera, Pinkowitz, Primakov, Rafferty, Rasha, Readersspeakout, Rouhani, Shape.com, spokesperson, Sreenivasan, Stayner, Teichner, tipster, Wigand, Yanayev

411, Agence, AJC, Al-Monitor, American-Statesman, BBC, debriefers, detectives, dispatcher, Engadget,

Enquirer, Fox Foxnews.com, Gizmodo, Herald-Leader, Huffpost, i09, interrogators, interviewer, interviewers, investigators, jailers, JEH, Journal-Constitution, jurors, Marketwatch, Mashable, MLB.com, Newsweek, NJ.com Oregonian, Politico, pollsters, Post-Dispatch, reporters,

Reuters, Review-Journal, Rhody, Sentinel, Showbiz Space.com, Star-Tribune, Sun-Sentinel, Sun-Times, Techcrunch, THR, Tribune-Herald, Tribune-Review, Union-Tribune, WBTV, Worldpost, Yediot, Yorio

biographer, boychik, grandkids, narrators, people, raconteur, Threepio

\begin{tabular}{ll}
\hline \multicolumn{1}{c}{ Category } & \multicolumn{1}{c}{ Pattern } \\
\hline $\begin{array}{l}\text { "Telling oneself" } \\
\text { expression }\end{array}$ & myself \\
Use for emphasis & lemme \\
Verbiage & somethin' \\
Verbiage: stories/jokes & joke, jokes, knock-knock, off-color, retold stories, story, \\
& $\begin{array}{l}\text { tale, tales } \\
\text { anecdote, anecdotes, fib, fibs, truth, untruth, untruths, } \\
\text { Verbiage: truth/lies }\end{array}$ \\
& whoppers, \\
\hline
\end{tabular}

Appendix C

Significant Patterns Within Top 50 Collocates of Let Know in the BNC

Category Pattern

Demands/requests for/

offers of information

Circumstances

Dominant clause

processes

Imperatives

mediately, possible, soon, tomorrow asked, thought, writing

ask, call, contact, phone, ring, try, write

References to mode of call, letter

communication

Modality

Obligation

could, do, gon(na), grateful, if, just, please, will, 'll

better, important, (at) least, must, ought, perhaps, supposed, should

Typicality/volition

Receivers

always, determined, sort (of), want, wanted

Subordinate clause

processes

doctor, manager, office, people

Verbiage

arrived, coming, doing, going, happening, knew, knows, wish

address, any, anything, arrangements, exactly, if, interested, outcome, when 
Misuro: Tell and Let Know: A Corpus-Based Study

\begin{tabular}{lll}
\hline \multicolumn{1}{c}{ Category } & \multicolumn{1}{c}{ Pattern } \\
\hline Verbiage: condition & alive & \\
Verbiage: opinions & feelings, stand, views & \\
Phrasal expression with let & be, it (let it be known) \\
know & & \\
\hline
\end{tabular}

\begin{tabular}{ll}
\hline \multicolumn{1}{c}{ Category } & \multicolumn{1}{c}{ Pattern } \\
\hline \multicolumn{1}{c}{ Verbiage: opinions } & comments, feedback, suggestions, thoughts \\
Exclamations & hey, ta, thanks \\
Participants & alarm, calendar, headlines \\
\hline
\end{tabular}

\section{Appendix D}

Significant Patterns Within Top 50 Collocates of Let Know in the COCA

\begin{tabular}{|c|c|}
\hline Category & Pattern \\
\hline \multicolumn{2}{|l|}{$\begin{array}{l}\text { Demands/requests for/ } \\
\text { offers of information }\end{array}$} \\
\hline Circumstances & below, meantime, soon, tomorrow \\
\hline $\begin{array}{l}\text { Dominant clause } \\
\text { processes }\end{array}$ & called, calling, contacted, nodded, reassure, stopping \\
\hline Imperatives & alert, call, contact, email, write \\
\hline $\begin{array}{l}\text { References to mode of } \\
\text { communication }\end{array}$ & $\begin{array}{l}\text { email, Facebook, glance, horn, messages, nod, phones, } \\
\text { postcard, signal, tone, touch, Twitter }\end{array}$ \\
\hline Modality & just, please, gonna, uncertain \\
\hline Obligation & courtesy, helpful, ought \\
\hline Typicality/volition & $\begin{array}{l}\text { eager, hesitate, pains, reluctant, shy, sure, wanna, want, } \\
\text { wanted, wanting }\end{array}$ \\
\hline Receivers & $\begin{array}{l}\text { anybody, anyone, Cosmo, everybody, everyone, folks, } \\
\text { readers }\end{array}$ \\
\hline $\begin{array}{l}\text { Subordinate clause } \\
\text { processes }\end{array}$ & $\begin{array}{l}\text { appreciate, appreciated, are, cared, cares, coming, } \\
\text { emailing, happening, happens, intends, kidding, messed, } \\
\text { proceed, receive, wins }\end{array}$ \\
\hline Verbiage & $\$ 100$, anything, episode, hashtag, how, what \\
\hline Verbiage: condition & alive, awake, okay, ready, safe, safely \\
\hline
\end{tabular}

